\title{
Fractured Atmospherics
}

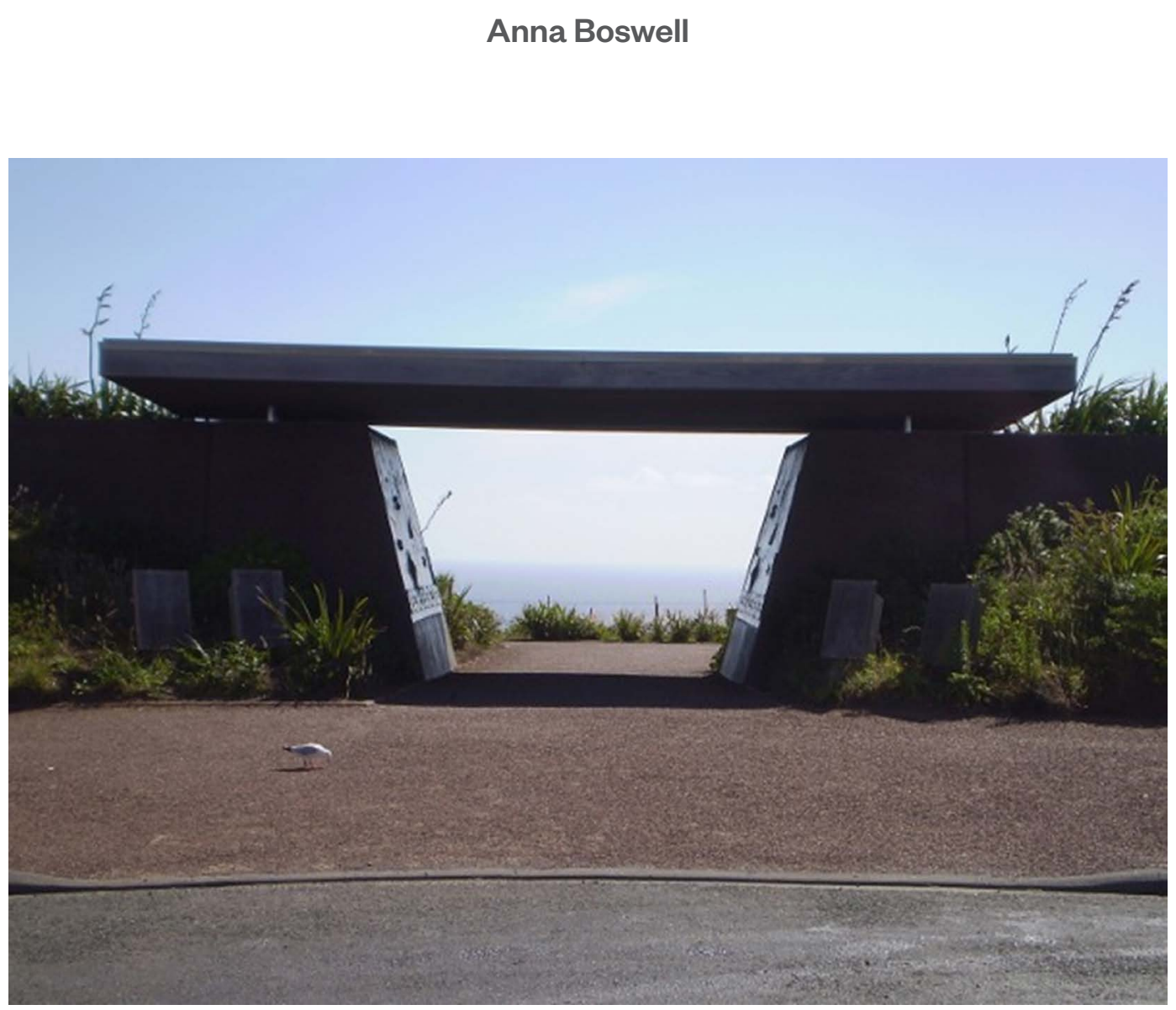

Fig. 1 Waharoa Gateway to Te Rerenga Wairua [Courtesy VirtualTourist.com]

\section{Angles of arrival}

As the caption explains, Figure 1 documents a scene at Cape Reinga or Te Rerenga Wairua, the northernmost tip of Aotearoa/New Zealand. It may seem relatively easy to identify the material elements depicted here: asphalt, a concrete waharoa or gateway, interpretative display panels, native vegetation, sea, sky, a gull. It is perhaps less easy to specify what the photograph is 'of'. Is this a picture postcard vista? A remote stop on a tourist itinerary? A national site of pilgrimage? A point of oceanic departure or return? An ancestral pathway? A sacred terrain? A ground of bitter historical dispute? Such connotative uncertainties have strong implications for what may be construed as the scene's atmosphere - which is in turn linked to its affective charge. Is a visitor invited to enter or warned against entry? Is the mood welcoming or foreboding? Should one look through the waharoa and imagine seamless passage? Or should one look at it, or be stopped short by it?

Affects and atmospheres are inter-implicated. They involve "lived circuits of action and reaction" (Stewart 2010: 339), traversing bodies and worlds, and the forces and intensities that permeate or shuttle between. As an experiential mode, affect dissolves firm boundaries: while one is moved to feel something on the inside, it will seem to come from the outside, as though the world is pressing in through the senses. Affect is individual, personal, interior, yet at the same time, it is collective, atmospheric, exterior; it is picked up and given off and involves the triggering of responses in individual and social bodies. For these reasons, affect is bound up with environmental fields and with 
ideas of mutuality and commonality, and while it is predicated on movement, it also has positing power. 'Something', it insists, is 'there'. The challenge of capturing or conveying this 'thing', or this sense of 'thereness' - its valences, vectors, shimmerings, cracklings, pulsings - can make language go flat ("words fail me"), or it can give rise to effusion, metaphor, poiēsis. Affect thus evades or exceeds semantic representation. It is extra-linguistic, a sign of surplus or surfeit, a modality of the sublime. The task - or the trick - of putting into words that which isn't ordinarily registered on the level of language is impelled by the prospect of gaining access to a heightened, more complete experience - of a place, say, or of something one intuits sharing with others.

Striving to make sense of the inside-out-ness and outside-in-ness of affects and atmospheres, Sara Ahmed observes that when we enter a room we may "feel the atmosphere", but what we actually feel is dependent on the angle of our arrival. Or, she explains, "we might say that the atmosphere is already angled; it is always felt from a specific point of view” (2010: 37). This paper mobilises Ahmed's notion of angles of arrival to examine incompatible structures of affect that underwrite a settler-colonial place. It asks: What if what is 'there' for you is not the same as what is 'there' for me? How might my experience of 'thereness' come under strain if I become aware that it offends (or is offended by) your sense of 'thereness'? And how might I be differently moved if what is there for me turns out to be an absence, or a negative imprint, which reveals the limits of our shared experience and the brokenness of whatever might be said to be between us? ${ }^{1}$

\section{Invasive design}

In Disagreement (1999) and The politics of aesthetics (2004), Jacques Rancière develops a framework for mapping "the distribution of the sensible", or what might be termed 'the sensible order'. According to Rancière, there are implicit laws that parcel out forms of participation in common social worlds, and they do this by inscribing modes through which these worlds can be apprehended or perceived. The distribution of the sensible, then, produces and regulates what can be seen, said, heard, felt and thought in a given situation or context. Importantly, for Rancière, "sensible" refers not to good sense or good judgement (although it will inevitably relay these connotations), but rather to what is capable of being apprehended by the senses.

Drawing extensively on examples from the ancient Greek world, Rancière's scholarship operates on the model of the polis, or city state, in which everyone is said to agree in principle on the sensible order that pertains (this, for Rancière, is the necessary basis for political disagreement; see 1999: $\mathrm{x}$ ). The settler-colonial state - of which there were many in the ancient Greek world, and which cannot likewise be said to possess a 'common' commons - remains beyond the purview of his theorising. Wilfully repurposing Rancière, however, and bridging his ideas with Ahmed's, we might say that while affect and atmosphere are interconnected, it is not the case that one can encounter or experience a place and feel absolutely anything at all. Rather, our responses are likely to be predisposed, based on the sensible order at work in and on and through us. Our bodies simultaneously "sense" and "make sense" (Massumi 2002: 2), but there is nothing universally given about how we arrive in an environment or react to what we will perceive as being its affective charge. In the first instance, our "personal sensibilities" (Zumthor 2006: 21) are culturally and historically patterned. Affect, then, is a matter of social aesthetics (which are, necessarily, political), as well as a matter of design.

Such reflections are of foundational significance in a place like Aotearoa/New Zealand. When Europeans first turned up here in the late eighteenth century, they encountered tangled forests, boggy swamps and a landscape crosshatched with tribal boundaries and the workings of tapu. Encounters documented in early voyaging accounts signal the visitors' inability to read the complex ways in which this place was already "written" through (Carter 2009; Boswell 2014). The violence of these encounters served to confirm European prejudices that the country and its inhabitants 
were anarchic, barbaric, primitive, savage. Having turned up in another culture's sensible order, these early European visitors, or "intruders" (Smith 2007), felt threatened by a local sensible order that they did not understand - by Indigenous ways of going about the place and organising life within the place.

Successive waves of settlers set about imposing their own order. By necessity, settlement is as much an imaginative undertaking as it is one of physically taking up residence, since settlers have to be able to respond in the right kinds of affective registers to the environments they construct in order to feel properly 'at home'. Imaginative and physical modes of occupation converge in activities such as mapping and surveying lands, felling forests, draining swamps, laying down communities, establishing institutions (churches, schools, governments, museums) and imposing a new language. Several key points can be noted in relation to this invasively transformative agenda:

1. In a so-called new world place, "enabling absences" (Rose 1999: 10) justify the reconstruction of landscapes and lifeways in order to supply what is deemed to be lacking (wheat fields, herds of livestock, urban centres, tourism resorts, recreation areas, etc.), as though the 'empty' land is crying out to be purposed in these ways.

2. Settler-colonial re-ordering is predicated on an assumed distance between humans and their environments. Since it involves converting supposedly idle 'space' into productive 'place', it is strongly tied to capitalist imperatives concerning property, ownership, individualism, economisation, and the binding acquisition or alienation of land as divisible and tradable commodity.

3. The re-ordering of place has powerfully geometric dimensions. Laying out lines, grids and templates across the surface of the land, it produces mathematicised topographies insensitive to existing contours and idiosyncrasies - the actual "lie of the land" (Carter 1996).

4. Space-time co-ordinates shift through this work of re-ordering. Settler culture is particularly concerned with ease of access in order to transport people in and resources and commodities out. The embedding of roading infrastructures, for example, will change how place is experienced temporally, and proximities will alter as a result.

5. There are pedagogical or instructional dimensions and a securing aspect to this work. Settlers have to be taught how to 'be' and to 'belong' in a so-called new world in order to allay their recurrent and palpable anxieties around identity, futurity, solidarity and groundedness. Settlement is, in other words, a thoroughly affecting and affective business, and it is bound up with longing (to be able to 'feel' the place, to have feelings for the place, to sense that you feel the same way as others do about the place).

6. Because European cultures privilege ways of seeing-as-knowing over the proximal senses, this re-ordering is primarily concerned with the visual dimensions of whatever the place seems to 'be'.

Textual traces from early phases of European exploration of Aotearoa/New Zealand disclose vivid affective responses to place. The Reverend Samuel Marsden, for instance, visited the Bay of Islands as head of the Church Missionary Society in New Zealand in 1819. Distinct surges are discernible in his journal when he arrives at the newly-founded mission station at Kerikeri. Marsden registers elation upon seeing a weatherboard house constructed from neatly sawn lengths of timber and marked out with gardens and picket fence. Momentarily torn in the classic affective bind between speechlessness and outpouring, he proclaims "our hearts overflowed with joy and gratitude", explaining "[w]e viewed the various operations with inexpressible delight, and considered them as the dawn of civil and religious liberty in this land of superstition, darkness and cruelty" (1932: 15051). This tableau is, for Marsden, an oasis of familiarity in an otherwise unintelligible place, and his 
response articulates the workings of a settler sensible order. Marsden reads the scene through an internalised template which in large part determines the nature of his affective response. Importantly, the atmospheric charge associated with this scene intimates a nostalgia for the future. In his mind's eye, Marsden can already picture a not-yet-marked-out mission school adjacent to the homestead, and an agronomic patchwork of rolling maize and wheat fields - tended by Māori converts - blanketing the surrounding hillside; this is the 'thereness' which becomes virtually tangible for him.

Settlement, then, is about transformation - it involves take-over and make-over or re-design - and settler culture tends to be up-beat about this, framing it, as Marsden does, as a future-oriented story of progress and advancement. Such temporal logic comes unstuck, however, because - as Marsden shows - settlement is always both 'before' and 'after' its own moment, and this selfdiscontinuity reveals that what is really at stake is reinscribing the place - writing over what is already there - with a new sensible order. In a setting like Aotearoa/New Zealand, such a sensible order may become dominant over time, due to the vigour with which it is pursued and the sheer weight of settler numbers, as well as the weight of the Europeanised structures of governance to which the place is increasingly subjected. Confident as this re-ordering may seem, however, settler culture cannot ever quite dispel the threat that the modes of belonging effected or enabled by its own sensible order are somehow - perhaps grossly - inadequate to the place.

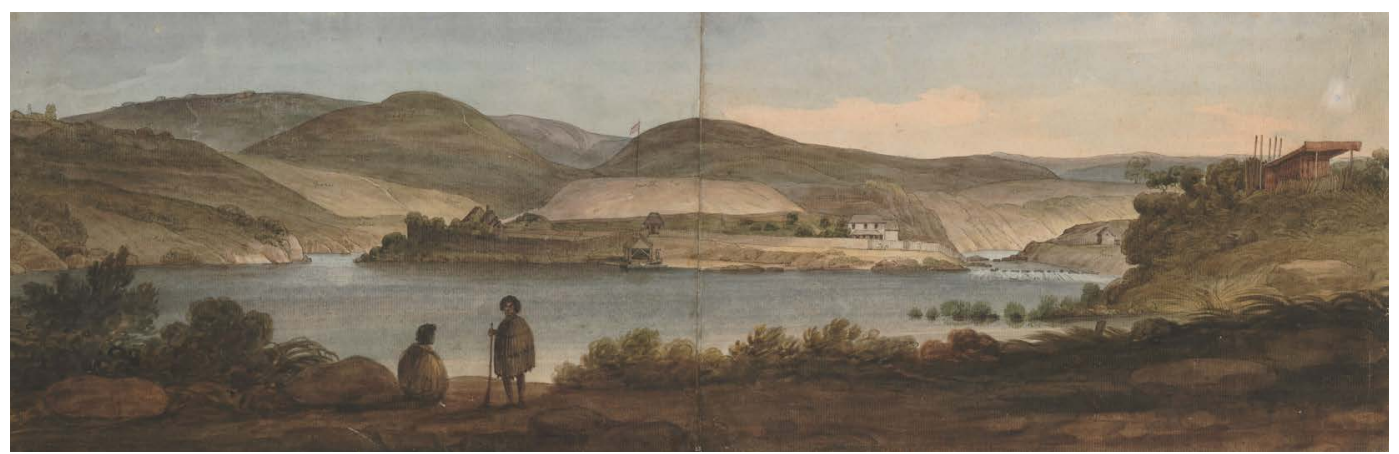

Fig. 2 Kiddy-Kiddy [i.e. Kerikeri] New Zealand, a church missionary establishment [Courtesy National Library of Australia]

In relation to Kerikeri, this threat is conveyed in a panoramic painting by Augustus Earle, an itinerant artist who visited the area a decade after Marsden's first trip. From a twenty-first century perspective, Earle's image possesses a nostalgic atmospherics of its own (velvety light, muted palette, the patinated aura that goes with being the oldest surviving artwork of the oldest surviving European building in the country). The painting gazes across the Kerikeri River towards the tiny stockaded mission on the other side. The 'absence' of an agronomic patchwork spreading over the hillsides may be read back on itself, as a sign of the slow progress of the mission. Importantly, because of its vantage point from Kororipo pā, the image also includes a carved Māori burial shelter on the neighbouring hillside, which stands as a marker of tapu and the tenacious hold of Māori funerary practices (Binney 2007). The painting is, in other words, shot through with the crackle of competing forces. ${ }^{2}$ Within the past decade, in fact, the privately-owned tourism ventures that presently occupy the burial ground at Kerikeri have been notified that they must relocate. Under mounting iwi pressure, the Department of Conservation has officially acknowledged that such ventures are "inappropriate developments or activities" on this sacred site (2007: 14). Indigenous sensible orders, Earle shows, may persist or resurface and fracture the superimposed atmospherics of place, bringing settler culture and its reconstructive agenda up short.

As this suggests, relations between affect and atmosphere, mediated by a settler sensible order, do not denote static or boxed-in positions which amount to "gridlock" (Massumi 2002: 3). Rather, they 
point towards ways in which affect can itself be moved. From a settler perspective it might seem, at Kerikeri, as though something has risen up out of the ground, spectre-like, or as though the ground itself has risen up in some spectral way. It is not the case that the ground itself is changed through this process, although, as Tim Ingold notes (2007: 45) in conceptual terms, cuts or breakages can reveal or create new surfaces, new 'faces'. What is changed is the way settlers themselves are able (or constrained) to experience the place. In facing whatever else might now seem to be 'there', they are in turn re-faced by it. Habituated affective responses to place might, in other words, be shifted as a result of precisely these kinds of sensible or atmospheric disjunctions.

\section{Brokenness}

Published sources offer at least five Māori expressions for atmosphere, and roughly forty for affect. ${ }^{3}$ These terms, however, are not strictly translatable. For iwi, the experience of place is characterised by hau (imperfectly glossed as wind, breeze, spirit, "the air we share”, Sturm \& Turner 2011: 32), which connects all entities within an environmental field. Hau involves a drawing in and releasing of breath which binds one to the long history of place and to the prior and primary forces that suffuse the lifeworld. Connected to the flow of mana (energies, presences, power) in the world, such forces may materialise in the mauri, or vitality, that animates all things, as well as in the responsibilities and regulatory codes associated with tapu. As with European notions of atmospheres and affects, tapu is felt rather than seen, and it is experienced as and through the workings of an operative sensible order - although it exceeds and refuses European notions of atmospheres and affects in key ways:

1. Tapu is an integral aspect of tikanga Māori, or first law (Mikaere 2011: 109), and it is bound up with rights and rightfulness (going about the place in the right way).

2. Tapu works explicitly in terms of sacredness. Making things 'uncommon', so that they can no longer be put to common use, it is twinned with noa (ordinary, common, non-sacred), producing a lifeworld characterised by spiritual balance (211-12).

3. Tapu and noa configure the lifeworld as a domain of social forces. They insist that all experiences and relationships are place-based, and that all places are experienced relationally (Shore 1988). ${ }^{4}$

4. Tapu carries the capacity to fracture or rupture other ways of understanding or experiencing place (such as those associated with the shorter history of European settlement).

One of the oldest representational traces of tapu-as-social-force is the oldest surviving Māori map, drawn by the northern chief Tuki in $1793 .{ }^{5}$ (Fig.3) This map transcribes an oral history, denoting a transitional phase in the Indigenous adoption of European technologies of writing; there is more than one sensible order operative here. The map is cosmological, metaphysical and mnemonic, inscribing tribal boundaries, whakapapa connections to land, chiefly residences and burial sites, as well as food, water and flax-gathering resources - all variously subject to the workings of tapu. Key among the elements detailed are Te Rerenga Wairua, the northernmost tip of the country and departure point of spirits of the dead on their homeward journey to Hawaiki; Te Ara Wairua, the spiritual pathway that runs the length of the country, culminating at Te Rerenga Wairua; and the pohutukawa tree used by the spirits to lower themselves into the water. What lies beyond the boundaries of the page - but is nevertheless implied - is the diagramming of the country in relation to a Pacific homeland.

Marsden's journal attests that Europeans initially struggled to grasp Tuki's teachings about Te Rerenga Wairua. In 1834, a Kaitaia-based missionary did, however, record a journey undertaken with the stated intention of cutting the sacred pohutukawa: 


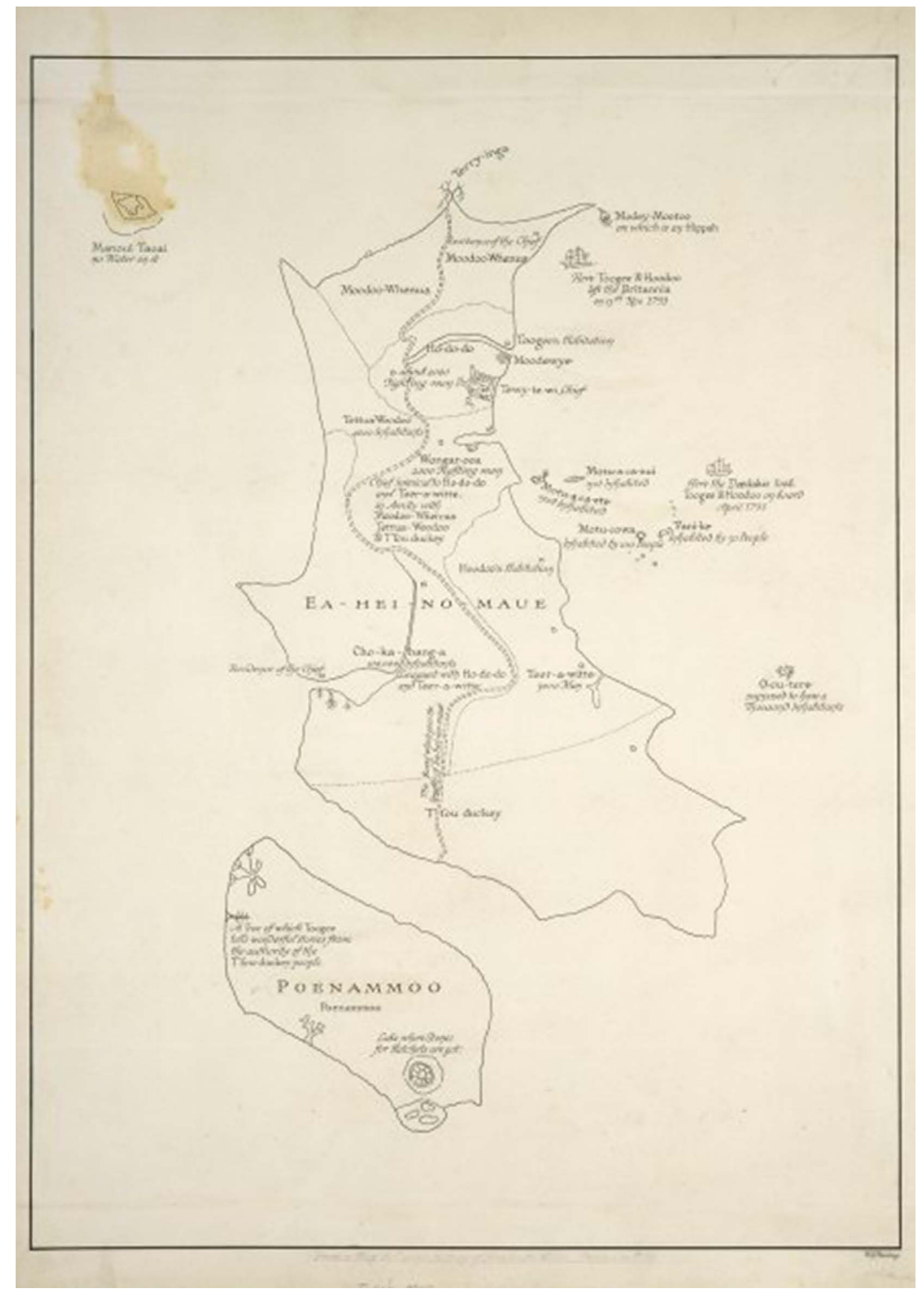

Fig. 3 Tuki's map [Courtesy Alexander Turnbull Library and Ministry for Culture and Heritage]

The scenery round the place where I stood was most uninviting; not only so, but calculated to inspire the soul with horror. The place has a most barren appearance, while the screaming of the numerous sea-fowl and the sea roaring in the pride of might, dashing against the dismal black rocks, would suggest to the reflecting mind 
that it must have been the dreary aspect of the place that led the New Zealanders to choose such situations as this for their Hell (W. G. Puckey, in Smith 1910: 464-65).

More recent settler accounts of visitation to the area, which was acquired by the New Zealand government in the 1960s as a scenic and scientific reserve, typically run along these lines:

Arriving at the Cape in the later afternoon, we sat quietly and contemplated the elemental nature of the experience. The last of the day trippers were at our backs [... ] The halt and the lame were trying to make their way down the tracks to get as close to the point as they could; with faltering steps and laboured breathing, they fixed their eyes on the distant sea beneath a sign that points to the equator 2066 nautical miles beyond [...] There is a sense of desolation at the Cape and yet it is exhilarating and frightening and awesome too. On that first journey we sat for a long time looking out to sea [. . . I I stood on the edge of the land feeling all of New Zealand behind me and I was almost tempted to leap myself, pushed by some sense of profound isolation to the world beyond (Kidman \& Ussher 1984: 75-78).

Despite being separated by 150 years, these two responses are internally templated in strikingly similar ways. Both are preoccupied with the fact that this locale is distant, elevated, exposed to the elements, windswept and 'godforsaken', and they construct the experience of place as constitutive of a deep individual self ('I' find myself here). From a European perspective, these surging affects connected with Te Rerenga Wairua have little to do with the hau of long history. Rather, they will likely be bound up with imported ideas about Christian wilderness, scenery appreciation and the sublime, and a subject who is given to 'feel' his or her own subjecthood through direct communion with Nature. They are also likely to do with leisure, travel and tourism as antidotes to settled urban life, and with remoteness and "edgeness" - implying a set of coordinates which diagram the place hemispherically, as antipodes. As the two responses also indicate, in accordance with its own changing needs (particularly national distinctiveness and connectedness-to-place), settler culture has adopted and reconstructed Te Rerenga Wairua as a place of emotional, patriotic pilgrimage. Since the 1960s, increasing numbers of settlers and tourists have journeyed to the northern tip of the country to be 'moved' and to find themselves 'at home'. Indigenous ideas about the site's spirituality have, in other words, been co-opted to produce a newly needed atmospherics of place.

To some extent, then, there appears to be consensus across settler and Indigenous cultures that Te Rerenga Wairua is special, and it is clear that the place maintains deep spiritual significance for all iwi. The place is not, however, a "common object" (Rancière 1999: xii) since the terms in which it works will differ depending on one's angle of arrival (i.e. what kind of sensible order is operating in each case). As Mason Durie has noted, the imposition of an imagined "universality" of feeling by settler culture in relation to such places mistakes Māori understandings of the nature of relationships between entities in a linked-up environment (2010: 239). At base, it misrecognises the fact that, following the pathway of Te Ara Wairua, iwi angles of arrival at this place emerge from long history itself.

Perhaps unsurprisingly, significant problems have flared in the space of this disjunction. Grievances concerning the site's ownership and governance by the Crown were lodged with the Waitangi Tribunal in the 1980s, as part of the Muriwhenua Land Claim. Visible signs of progress (from a settler perspective) are, for Ngāti Kuri and other Muriwhenua tribes, a form of scarring or defacement and a desecration of the place. Accordingly, iwi representatives requested that the lighthouse and other residential and commercial properties marking the area be removed. When progress in this direction proved too slow, graffiti and arson were deployed in response. Despite this increasingly fraught atmosphere, or perhaps as a strategy to ease escalating tensions, the New Zealand government announced in 2000 that Te Rerenga Wairua would become the site of the first iwi museum in 
the country. A tender was held, an architectural design was produced, and preparations reached the advanced planning stage. The development, however, has proven un-implementable, which is to say that - in opening splits between new country and old, short history and long - it exposed unbridgeable cracks between operative sensible orders.

Circumstances surrounding the decision not to proceed with the museum are complex and involve unresolved disputes over the site's ownership and management, as well as conflicting commercial aspirations (Boswell 2011). What is perhaps most striking, however, is that the planned museum development fundamentally mistook the tapu nature of the site itself. The prospect that existing desecrations would be removed only for the site to be re-desecrated became particularly contentious. At public meetings, iwi representatives talked about their wairua, or spirit, being made heavy and saddened by this. "Who do we think we are to tutu with the spiritual world? To put land marks over the marks of nature?”, ran one anguished vein of questioning (Marika 2008). As is the case at Kerikeri, the tapu associated with Te Rerenga Wairua is such that visitation must be discouraged by its kaitiaki, or guardians, as a precondition for maintaining the site on behalf of a larger social body.

Ngāti Kuri concerns have centred on the actions of Department of Conservation contractors in transforming Pae, the sacred mountain at Te Rerenga Wairua, into "a crater" (2008). In accordance with the invasive logics of settler design, the top of this mountain was levelled in order to supply the soil used to re-contour the visitor car park and to create the banks within which the concrete waharoa has been set. Such wounding of the place, in violation of tapu, points towards the limits of European notions of affect, understood as the experience of a person or persons within a place, rather than as a property of the place itself. In other words, Te Rerenga Wairua - in the tapu figure of Pae, ancestor, spiritual entity and symbol of identity (Mead 2003: 67) - possesses wairua and has the capacity to be corporeally and spiritually affected by an unfolding history of use and care. The implications are considerably more far-reaching than those associated with European anthropomorphisms conventionally overlaid on the land and embodied in the Romantic conceit of Nature personified. In the terms of an Indigenous worldview, people and place are placentally connected 'of' each other. ${ }^{7}$ For tangata whenua, or Indigenous people, this bond means that the land feels you before or at the same time as you feel it. You press on its senses in the terms of a living relationship that is ethically binding, and you are subject to - both faced and given a face by - its own sensible order.

As a flashpoint, then, Ngāti Kuri distress at harm perpetrated through the 'remediational' earthworks, which triggered the Department of Conservation abandonment of the proposed iwi museum development, marks a moment where settler culture has been confronted by the fact that it cannot feel the place, or that it feels the wrong way for the place - in part because it has failed to understand that the place itself is charged with feelings that demand consideration. The place and its longer and ongoing history of Indigenous habitation exceed settlers' feelings for it and their designs on it, which offer only circumscribed modes of longing and belonging. What is 'moved' is the imagined ground of a shared understanding that functions, ordinarily, as the "national orthodoxy" (Barclay 2003: 9). Faced with the assertion of pre-existing and ongoing 'uncommonness', the settler response to place is reduced to something less than the wholeness which it has hitherto conceived itself as constituting. At such moments, what settlers feel amounts to a splintering of their own sensible certainties, precipitated by an upwelling of alien affect. The land is re-experienced as an interior place of history and habitation, to which the secondary, exteriorising, future-oriented work of settlement cannot lay claim, and which it cannot contain or subdue. ${ }^{8}$ What is returned to settlers, in affective terms, is the shaky grounds of their place within this place - an atmospherics of precarity and self-disorder which isn't reducible to the profoundly European category of the sublime. ${ }^{9}$ 


\section{Disabling absence}

The logic that would have produced the iwi museum at Te Rerenga Wairua is bound up with "enabling absence", although again, as with Earle's painting, it is possible to read this absence back on itself. The museum, then, is a disabling and disabled absence. It is a 'thereness' which must remain virtual, an object of nostalgia for a future-that-can't-be. In practice, as the levelling of Pae Rehua attests, Te Rerenga Wairua has been re-ordered. Tar-sealing of the northernmost stretch of State Highway One did go ahead, although facilitating ease of access by linking the site to a "navigable" path of asphalt (Solnit 1999: 365) was bitterly contested. Existing buildings at Te Rerenga Wairua except for the lighthouse have been removed, and a handful of interpretive panels have been installed. As a compromise between competing sensible orders, these measures of 'un-doing' mark the limits of whatever can be said to be shared at Te Rerenga Wairua. There lingers, however, a distinct atmosphere of unease: Department of Conservation files specify that these developments must be arson- and chainsaw-proof (see Boswell 2011: 236), and bodies were laid on the line in protest when the bulldozers arrived.

The key element of the originally-commissioned design that has been implemented at Te Rerenga Wairua is the monumental concrete waharoa, or portico (Fig. 1). Withholding immediate views of the ocean, this waharoa seems intended to appear 'at home' in its surroundings and to orchestrate drama in the visitor's encounter with the site. As a mechanism for angling arrival, however, its function is complicated by the enlarged renderings of Tuki's map imprinted on its concrete surfaces. Problems also coalesce around a new ablution block adjacent to the waharoa (just out of view in Fig.1). The Department of Conservation insisted on this noa facility as critical infrastructure for visitation purposes, but it is incompatible with the tapu nature of the place. It, too, is adorned with renderings of Tuki's map. Such uses of this tribal taonga, or prized possession, have been publicly condemned by Ngāti Kuri representatives, who note that the Department of Conservation agents have "built a shit house by any other name in the midst of an ancient map of Aotearoa, embellished with [...] sacred symbols whose significance is lost to them" (Gregory 2009). The orientation of the waharoa itself is erroneous, Ngāti Kuri further point out (2008). The structure faces in the wrong direction and is misaligned with Te Ara Wairua, impeding and obscuring the hau of long history. Of paramount concern to iwi representatives, however, is the fact that the bank within which the waharoa is set, and the ground which it occupies, embody - at the same time as they conceal - the desecration of Pae Rehua. The waharoa, then, is perhaps materially most significant for the "absent presence" it marks - for what lies beneath the surrounding surfaces of asphalt and flax, are the grounds of knowledge instantiated in the disfigured entity of the sacred mountain. If Tuki's teachings about forces of tapu associated with Te Rerenga Wairua remain largely opaque or illegible to settler culture, what affect seems to reveal at this place is the brokenness of settlement history itself. The imaginative construction of this place by settler culture as a source of 'fullness' and 'commonness' in affective and atmospheric terms is, quite literally, predicated on the interment of Indigenous knowledge and the effacing of prior modalities of response. 


\section{References}

Ahmed, S. (2010). Happy Objects. In M. Gregg \& G. Seigworth (Eds.), The affect theory reader. London, UK: Duke University Press. (pp. 29-51)

Barclay, B. (2003). Celebrating Fourth cinema. Illusions 35, 7-11.

Binney, J. (2004). Tuki's Universe. New Zealand Journal of History, 38 (2), 215-32.

Binney, J. (Ed.) (2007). Te Kerikeri 1770-1850: The meeting pool. Wellington, NZ: Bridget Williams Books.

Boswell, A. (2011). ‘Shakey notions': Settlement history on display [unpublished PhD thesis, The University of Auckland].

Boswell, A. (forthcoming in 2014). The sensible order of the eel. Settler Colonial Studies special issue, Other people's country: law, water, entitlement.

Calder, A. (2011). The settler's plot: How stories take place in New Zealand. Auckland, NZ: Auckland University Press.

Carter, P. (1996). The lie of the land. Boston, MA: Faber.

Carter, P. (2009). Dark writing: Geography, performance, design. Honolulu: University of Hawai'i Press.

Department of Conservation (2007). Sustainable development plan for the Kororipo-Kerikeri basin [unpublished report].

Durie, M. (2010). Outstanding universalvalue: How relevant is indigeneity? In R. Selby, P. Moore \& M. Mulholland (Eds.), Māori and the environment: Kaitiaki. Wellington, NZ: Huia.

Gregory, B. (2009). Te Rerenga o Nga Wairua aka Cape Reinga NZ Jan O9 Movie. maori.org.nz. Retrieved from https://www.youtube.com/watch?v=BQleDk_EeOo [accessed 21 August 2014]

Ingold, T. (2007). Lines: a brief history. London, UK: Routledge.

Kelly, J. (1999). Maori maps. Cartographica: The International Journal for Geographic Information and Geovisualization 36 (2), 1-30.

Kidman, F. \& J. Ussher (1984). Gone north. Auckland, NZ: Heinemann.

Marika, A. (2008). Excavation devastation at the Cape for $\$ 14.5 \mathrm{~m}$ tourist centre etc From the Original Whakapapa Club. Questions and answers on Cape Reinga work (posted 01/03/2008). http://www.maori.org.nz/papapanui/ archives/viewthread.php?TOPIC ID=3710\&Page=13 [accessed 16 Sept, 2014]

Lamb, J. (1991), A Sublime moment off Poverty Bay, 9 October 1769. In G. McGregor \& M. Williams (Eds.), Dirty silence: Aspects of language and literature in New Zealand. Auckland, NZ: Oxford University Press.

Marsden, S. (1932). The letters andjournals of SamuelMarsden, 1765-1838, J. R. Elder (Ed.). Dunedin, NZ: Coulls Somerville Wilkie.

Massumi, B. (2002). Parables for the virtual: Movement, affect, sensation. Durham, NC: Duke University Press.

Mead, H. M. (2003). Tikanga Māori: Living by Māori values. Wellington, NZ: Huia.

Mikaere, A. (2011). Colonising myths - Māori realities: He rukuruku whakaaro. Wellington, NZ: Huia.

Moorfield, J. C. (2011). Te aka: Māori-English, English-Māori dictionary and index. Auckland, NZ: Pearson.

Nga hapu o Ngāti Kuri. (2008). Te Rerenga o Nga Wairua aka Cape Reinga, Nth Is - NZ. maori.org.nz. Retrieved from https://www.youtube.com/watch?v=S5SB8VUftjo [accessed 19 Sept 2014]

Ngata, A. T. (ed.) (1901). Complete manual of Maori grammar and conversation, with vocabulary. Christchurch, NZ: Whitcombe and Tombs.

Ngāti Kuri. (2008). Te Rerenga o Nga Wairua aka Cape Reinga, Te Hiku o Te lka (Nth Is - NZ) maori.org.nz. Retrieved from https://www.youtube.com/watch?v=FEszKmbTMco [accessed 21 August 2014]

Park, G. (2006). Theatre country: Essays on landscape \& whenua. Wellington, NZ: Victoria University Press.

Rancière, J. (1999). Disagreement: politics and philosophy, J. Rose (trans.). Minneapolis, Ml: University of Minnesota Press.

Rancière, J. (2004). The aesthetics of politics: The distribution of the sensible, (G. Rockhill Trans.). New York, NY: Continuum.

Rose, D. B. (1999). Hard Times. In K. Neumann, N. Thomas \& H. Ericksen (Eds.), Quicksands: Foundational histories in Australia and Aotearoa New Zealand. Sydney, NSW: University of New South Wales Press.

Shore, B. (1988). Mana and tapu. In A. Howard \& R. Borofky (Eds.), Developments in Polynesian ethnology. Honolulu: University of Hawai'i Press, 137-73.

Smith, J. (2007). Post-cultural hospitality: Settler-native-migrant encounters. ARENA Journa/ 28, 65-86.

Smith, S. P. (1910). The Maori wars of the nineteenth century. Christchurch, NZ: Whitcombe and Tombs.

Solnit, R. (1999). Savage dreams: A journey into the landscape wars of the American West. Berkeley, CA: University of California Press.

Stewart, K. (2010). Worlding refrains. In M. Gregg\& G. Seigworth (Eds.), The affect theoryreader. London, UK: DukeUniversity Press.

Sturm, S. \& S. Turner (2011). "Built pedagogy": The University of Auckland Business School as Crystal Palace.

Interstices 12, 23-34.

Turner, S. (2010). The truth of waters. Reading Room 4 (10), 112-23.

Turner, S. (2002). Being colonial/colonial being. Journal of New Zealand Literature 20, 39-66.

Williams, H. W. (1957). A dictionary of the Maori language. Wellington, NZ: Government Printer.

Zumthor, P. (2006). Atmospheres: Architectural environments, surrounding objects. Basel: Birkhäuser.

This paper has been double blind reviewed. 


\section{Endnotes}

1. I am indebted to Turner's work on broken history (2002).

2. While my analysis builds on Calder's (2011:46), I am explicitly concerned with tapu as social force, and with its capacity to rupture modes of belonging associated with short history.

3. See Ngata (1901), Williams (1957) and Moorfield (2011).

4. Shore makes this observation in the context of the wider Pacific. It is linked to the "epistemological bias" that things be known "in their specific contexts and through their perceptual effects in the world rather than in terms of essential, intrinsic features" (Shore 1988: 138).

5. See Kelly (1999) and Binney (2004).

6. "Edgeness" is a branding strategy for the settler nation. See http://www.nzedge.com/about/ [accessed 20 August 2014].

7. Whenua, the Māori term for land, also means afterbirth. See Park (2006: 240-44)

8. I draw here on Barclay (2003) and Turner (2010). See also paragraph 2 of this paper.

9. The sublime suggests that whatever settlers feel isn't 'of' the place. See Lamb (1991) for an alternate analysis of the settler-colonial sublime. 